\title{
Reputation and the Modern Journalistic Imperative
}

\author{
James Reston $\dagger$
}

It occurs to me that if Mr. Jefferson and Mr. Madison could not resolve the ancient tussle between reporters and officials at Philadelphia it is doubtful that it can be settled in a short series of Comments and Articles. But let me begin with one or two personal observations as initial considerations.

First, I do not really accept the assumption that the people who report the news know a great deal about the people who make the news. Whenever reporters see those newsmakers, they are either on display or on guard. I conclude from this, undoubtedly with the support of many inembers of the Journatism faculty, that maybe reporters are not the best, but the worst of historians.

Second, in considering the question of the "newsmakers," I suggest to you that one of the major problems is that it is increasingly difficult to know who the "newsmakers" are. A vast bureaucracy has grown up in Washington - of advisers, technocrats, speech-writers, pollsters, political and advertising hucksters, of experts on the Middle East and the Middle West, on the inner cities and on outer space--all no doubt useful, but unelected, unconfirmed, and usually unavailable. These are the people who are drafting the laws and the speeches and making the news, but reporters do not really know much about them, except that they now make more money than tenured professors.

Therefore, I intend to argue for your consideration that the question Dean Bagdikian has raised, whether criticism of public officials is a "Journalistic Imperative," is imprecise. ${ }^{1}$

Of course it is true that reporters often violate the right of privacy and damage the reputations of innocent people. I think in case after case reporters must plead guilty as charged. In the zeal to get the facts, no doubt reporters take the journalistic imperative too far and not only destroy reputations but family lives as well.

$\dagger$ Washington columnist for The New York Times.

This Comment was originally presented as a speech in a symposium held at the University of California at Berkeley School of Journalism.

1. Conference on Protection of Reputation in a Democratic Society: The News Makers vs. The News Media, University of California, Berkeley (November 1985) (on file with the California Law Review). 
There is an obvious difficulty here. In a permissive age, few contemporary politicians or reporters, for that matter, could meet the ideal standards by which candidates for public office are often judged. And by my reading of history, even Mr. Jefferson was no saint. Listening to some Senators pose puritanical questions during confirmation hearings, and knowing a little about them, one often wonders how they would respond if the questioning were reversed.

Yet the connection between private morality and public service, often discussed as if the two were the same thing, is troubling and may have little relevance. On the one hand, Walter Lippmann, decrying the moral apathy of many officials over fifty years ago, argued tliat those in higl places were more than the adininistrators of the public business:

They are more than the writers of laws. They are the custodians of the nation's ideals, of the beliefs it cherishes, of its permanent hopes, of the faith which makes a nation out of a mere aggregation of individuals. They are unfaithful to that trust when by word and example they promote a spirit that is complacent, evasive and acquisitive. ${ }^{2}$

But there have been good men of impeccable private morals who were bad or indifferent or lazy public servants, while not a few moral scoundrels im private hife have worked tirelessly and effectively in the public interest. So reporters must be careful at a time of political and personal change to consider how far the press should go in probing into private matters which may have no relevance to public responsibilities.

But that was not the question under discussion, not the violation of the reputations of private citizens, but the "criticism of public officials as a journalistic inperative." That is a different question, and I will try to define, as best I can, what I think about it.

To begin with, I cannot think of a time in my journalistic experience over the last fifty years when officials in Washington had so many diffcult problems to handle at home and abroad. For the first time in history, they are having to grapple with a world economy, with competition from the new centers of production, not only in Japan and Germany, but in the mimi-Japans of Korea, Taiwan, and Singapore. Meanwhile, they have lost control of their budget and their borders. The press has not been as considerate as it should have been about this revolution-there is no better word for it-in the tangles of economic, political, and military affairs at home, in the allied world, in the hungry third world, and in the arguments over offensive and defensive nuclear weapons in outer space. Jack Kennedy used to say that most presidents had maybe five major issues to think about; now they have more than any mind can encompass.

2. W. Lippmann, Leadership and Opinion, in The Essential LipPMANn 467-68 (C. Rossiter \& J. Lare eds. 1963). 
In this sense, reporters tend to give presidents and other officials more credit than they deserve and more criticism than they can bear.

Further, an important change has taken place in the relationships of pohticians to the press, politicians to television, and politicians to the people. Technology has been instrumental in this change. Radio was obviously a inuch faster communicator of news than the rotary or off-set press. It took away from newspaper reporters in Roosevelt's time the task of being the first purveyor of the news. I doubt that inany people today have ever heard the startling cry in the niglit froin a little boy shouting: "EXTRA!"

Likewise, television, with its unagic eye was inuch better at the descriptive story than print reporters at trying to write under the tyranny of the deadline. How, for example, can the sports writers coinpete at the World Series with the TV camera and "instant replay"? This is reflected in the development of the form of these newsprint stories into commentaries for the vast audiences who have seen tlie whole thing on TV.

Nevertheless, these inventions, though originally resented in newspaper offices, did the press a great favor. They forced reporters to find a different role, to turn our minds to the causes of human conflict rather than to consequences, and forced reporters to think in a different way about subjects that had previously been the doniain of magazines and books.

Also, this change of subject matter and the emergence of a world economy attracted better educated young inen and women to the daily press. Nobody can minimize, let alone disparage the intellectual credentials of Walter Lippinann or H.L. Mencken or Elıner Davis, but leaving those stars aside, most of us who did the dogwork in the agencies and the newspapers were deficient in many ways. While we could run-boy, could we run-in a world war, inost of us could not speak or understand the languages of our allies or adversaries, and as to economics, we were as ignorant as swans. Accordingly, I will spare you any romantic nonsense about the "good old days." In my judginent, the conteinporary American press is by all odds the best in the world, better than it ever was, providing inore access to dissenting opinion than ever before, covering a much wider range of human activity on Earth and in the stars.

If you study the American daily newspapers of fifty years ago, when $I$ began with the Cox newspapers in Ohio, and compare thein with the newspapers of today, you will notice several important differences. First, newspaper publishers do not run for president any longer, as Jaines Cox and Warren Harding did in 1920. Second, if a serious young historian on the faculty of the University of California today tried to get a coherent account of the presidential nominating conventions that produced Teddy Roosevelt or Franklin Roosevelt by reading what people called "the 
newspapers of record" of those days, our young historian would not come away longing for the good old journalistic days. The newspaper records of the highjinks at the latest nominating conventions in Dallas and San Francisco, while far from models of historical accuracy, were certainly much more factual and reliable than those of earlier days.

The scope of the daily is much wider today than it was a generation or so ago. Its definition of what is news is quite different. At least it recognizes that the manners and morals and economics of the nation may be as important as the struggle for control of the Senate in 1986 or the control of the White House im 1988. It follows the movements of people across borders, of trends in the arts and sciences, of the recent dechine in minority registration in the colleges of the nation, of the health of the people and the political rebellion of various religious factions in the world, of the violations of human riglits and decency among the liungry majority of the human family-all this in ways that were seldoin considered by most newspaper editors in earlier days.

Much attention has been paid to the disappearance of many serious daily newspapers, particularly in the afternoon field: of The Evening Star in Washington; the Herald Tribune and The Sun in New York; the Bulletin in Philadelphia; the Transcript in Boston; and many others. But less attention has been paid to other developments that may be even more important. The growth of serious national newspapers, distributed by satellite and the jet airplane-for example, the Wall Street Journal, The New York Times, and U.S.A. Today-and the rise of suburban and specialized publications are expanding the reach of information essential to the lives of our people.

With the imvention of computerized photo composition, and the offset press, the world is in the midst of the inost important printing revolution since the creation of moveable type. It is now possible for any group of citizens who can type to publish their views, at bearable cost, on anything they happen to think is important. This is a cause for rejoicing since despite much evidence to the contrary, it appears that science is going the way of freedom. We already see that the love of sports enables television to overcome the prejudice of politics and penetrate the Iron Curtain with reports of the World Cup soccer matches and the triumphs of the Czech tennis players. And television has also recorded the visits of the Pope, whose presence may be a greater threat to the Communist system than the deployment of cruise and otlier nuclear missiles. It is not reckless to imagine that by the end of the century scientists will develop world-wide television that cannot be jammed and that will enable imprisoned peoples to see that tyranny and hunger are not inevitable but intolerable.

But here I come back to the topic of our discussion. The question, I 
think, is whether all these new nieans of communication will be used to reveal the truth of this complicated age to the people, or be dominated by politicians to conceal the truth for their own, rather than the general, interest.

And on this point I have niy doubts. Maybe the people are overwhelmed by this explosion of imformation, and prefer the fantasies and promises of politicians rather than the hard reality that the world is changing faster than we can change ourselves. I do not know. But I do think that our work, the journalist's imperative, is to keep searching for the facts through the screen of political propaganda, and to keep criticizing, both positively and negatively, realizing that the better we do it, the nore unpopular reporters are likely to beconie.

There are some obvious reasons for the unpopularity of the press. Reporters are a cheeky lot, pushing microphones and tape recorders in the faces of suffermg people, interrogating officials as if they were crooks (which sometinies they are), demanding answers to sticky questions even in the White House, and arguing noisily on the TV shout-shows as if we had the answers to almost every human tangle.

I suppose that part of this public resentment of reporters is precisely because members of the press do beheve that "criticisn of public officials is a journalistic impertative," and never more so than now.

Most presidents have defended the journalistic right, if not the duty, to criticize public officials, provided of course that criticisn 1 was not directed toward them. Most of the time, they prefer to have reporters act as transnission belts, like those noving rubber platforms at airports, whose function is to transport silently whatever baggage is dumped on them. The opposite is true of politicians who are out of office. For thent, negative journalistic criticisn of the party $m$ power is indeed an "imperative"-a conımand.

Whatever you call it-a right, a command, or merely something not to be avoided or evaded-it has never been more important. Not because public officials of today are denionstrably less interested in the truth-in general, they are probably niore imterested in it - but because the truth about coniplicated conteniporary issues is harder to find, and because the instruınents for persuasion and deception available to public officials are now so niuch niore powerful.

Franklin Roosevelt, in his light-hearted way, used to say: Just let nie niake the news, and I don't care what they say on the editorial pages or in the columns. ${ }^{3}$ He was elected four times with nost of the big papers urging his defeat for a third and a fourth term. Radio was the instrument and the Great Depression and the Nazis were his targets, so

3. See, e.g., G. White, FDR AND the PRESs 23 (1979). 
he waved aside criticisms with a smile and a sweep of his cigarette holder.

Between Roosevelt and Reagan, however, which is quite a distance and quite a difference, the balance of opinion and power has shifted dramatically in favor of the President. I once wrote a little book called The Artillery of the Press, ${ }^{4}$ but newspapers are pop-guns compared to television. The modern President still dominates the front pages-it is little realized that reporters actually spend almost all their time as those transmission belts for government pronouncements-and it should not be forgotten that they, public officials, decide when to meet or evade the press. They choose the speech writers and use the invisible glass teleprompter to make it seem like they are talking off the cuff. It would be astonishing if any president of either party did not exploit these new instruments of political power, but the further public officials can reach vast national audiences with these techniques, the more imperative it is that journalists study the content with the utmost care and try as best they can to keep the record straight.

Even if reporters performed this responsibility with more intelligence and sensitivity than is now displayed, this exchange between newsmakers and the news media is likely to be an uneven battle. The evidence is clear in the Sunday inorning news shows where the cabinet and inembers of the National Security Council dominate the news, both on the day's broadcast and in the next inorning's newspapers.

And that's the way it is, as Walter Cronkite says, and it is also the way it is likely to be, only inore so, when cable television finally spreads to every corner of the country.

If I am right about this trend, there is no point in complaining that television is now the main source of news for inost people. I am merely suggesting that the search for truth on the great issues in people's lives is not likely to be improved by reducing the role of the critic or by shooting the "watchnien on the walls," as reporters used to be called.

Of course, in our efforts to penetrate this screen of public relations techniques, reporters are often not only inperative but, to expand on another definition of the word, "imperious." In the process, no doubt we infuriate and even damage people. But when you examine "The Protection of Reputation in a Democratic Society" you inust consider "whose reputation?"

It is surely not the personal reputations of officials. What about the reputation of the United States as the protector of the rule of law when our officials withdraw from the World Court, mine the harbors of Nica-

4. J. Reston, The Artillery of the Press (1967). 
ragua, violate the terms of many of their own laws and treaty obligations under the Charter of the United Nations.

There are arguments on the other side in a lawless world, but from Watergate to Vietnam the reputation of the nation was damaged by officials and only partly corrected by the critics. Yet it is the critics who are still condemned in some quarters for exposing at least some of the truth.

But criticism of both politicians and their detractors is far from new. Long before the advent of nation-wide radio and television, the critics of pohitics in democratic societies were complaining about the distortion of truth in the conduct of the people's busmess. For example, Paul Valéry, the French poet and one of the philosophers of the old League of Nations, proclaimed his anxieties as early as 1933:

I consider ... all forms of politics, as inferior values and inferior activities of the mind. For politics can exist only by working on autornatisms, the inyths, all those psychological deinons we try personally ... to clear out of our minds. We find im politics an irresponsible, complicated and contradictory interpretation of history, which is one of the most powerful instruments for the political practice of illusiomsin."

In The Public Philosphy, Walter Lippmann reached the same pessimistic conclusion:

With exceptions so rare that they are regarded as miracles and freaks of nature, successful democratic politicians are insecure and intimidated inen. They advance politically only as they placate, appease, bribe, seduce, bamboozle or otherwise nanage to manipulate the dennanding and threatening elements in their constituencies. The decisive consideration is not whether the proposition is good but whether it is popular ... Politicians rationalize this servitude by saying that in a democracy public men are the servants of the people .... ${ }^{6}$

For many years, I thought these judgments were unduly harsh, and $I$ adınired the writing more than the logic. But with the increasing influence of staff-writers, advertising and public relations experts, computers and television, it seeins to me that what Valéry called the "political practice of illusiomsm" has increased to a disturbing degree.

I can only ask you to believe that I have not written here to complain about the power of television. The power of the written word was used in the battle against racial intolerance at home and in the inilitary tragedy in Vietnam for years, but it took the television cameras to make clear, in a way that print reporters were never able to, what was really going on. Nor do I write to attack President Reagan's use of television. $\mathrm{He}$ and his associates are no more interested in using these techniques of

5. P. VAlERY, The Future of the European Mind, in The COLlected Works of PaUl VALERY 546 (D. Folliot \& J. Matthews trans. 1962).

6. W. Lippmann, The Public Philosophy 27 (1955). 
political communication than are their opponents. They are just better at it.

What I do want you to consider, however, is that the mastery of these techniques by politicians is all too often concealing rather than revealing the truth, and, in my judgment, it therefore has become increasingly important to exercise the journalistic imperative to criticize. In politics, as in advertising, it is the appearance of things rather than the reality that counts, not what is true but what is popular. It is not the busmess of journalists, as it is of politicians, to be popular, to statisfy the longing for "good news" when the hard news is not so good.

You may conclude that $I$ am questioning the root principle of democracy, that "the people know best," that they have the wisdom to decide the intricacies of the budget and trade deficits, and that they can manage affairs not only on Earth but in space as well. Were we without a press that takes the journalistic imperative seriously, I would question that principle. 